\title{
Determining the Level of Environmental Sustainability Practices at Campus Dormitories Using Green Indicators
}

\author{
Lailatulfariha Mamat ${ }^{1}$, Noor Ezlin Ahmad Basri ${ }^{1}$, Shahrom Md Zain ${ }^{1} \&$ Elfithri Rahmah ${ }^{2}$ \\ ${ }^{1}$ Faculty of Engineering \& Built Environment, The National University of Malaysia, Selangor, Malaysia \\ ${ }^{2}$ Institute for Environment \& Development, The National University of Malaysia, Selangor, Malaysia \\ Correspondence: Noor Ezlin Ahmad Basri, Department of Civil \& Structural Engineering, Faculty of \\ Engineering \& Built Environment, The National University of Malaysia, 43600, Bangi, Selangor, Malaysia. Tel: \\ 6-038-911-8342. E-mail: ezlin@eng.ukm.my
}

Received: September 4, 2014 Accepted: November 28, 2014 Online Published: April 30, 2015

doi:10.5539/ass.v11n12p25 URL: http://dx.doi.org/10.5539/ass.v11n12p25

\begin{abstract}
Environmental pollution and degradation at university campuses occurred due to various daily activities by the residents. The provision of support services in the residential and dormitory areas in the form of energy and materials consumption are growing into concerns nowadays. In this study, indicators of environmental sustainability were developed to identify the level of sustainability at dormitory areas. The indicators should be able to convey information easily without losing too much information or creating too much distortion. There are numerous aspects that need to be considered when discussing about environmental sustainability. In order to achieve the appropriate requirement for green dormitories, various references were used based from their practices locally and internationally. The indicators proposed for this study focused on four main environmental sustainable categories which are solid waste management, water resources management, green office practices and education and awareness. Each dormitory was evaluated using the proposed indicator based on the information provided by the dormitory representatives. The score for each indicator was summed up to determine the performance of each dormitory which reflected their sustainability achievement. With the help from the respondents who represented their dormitories, some points that may be the constraints of practicing the sustainability concepts are suggested. Some suggestions were made to improve the dormitories sustainability level. At the end of this study, all dormitories were ranked in the order of their performance based on the total marks obtained from the indicator calculations. From this study, it shows that KIZ scored the highest by 44 marks while KTHO the lowest with 4 marks. As a conclusion, there is a huge difference in sustainability practices between dormitories since there are different management approaches.
\end{abstract}

Keywords: indicators, dormitories, sustainability

\section{Introduction}

Introducing 'Green indicators' in this paper, it gives a brief definition on a study which indicates the level of green practices that contributed by each dormitory. There are four main aspects of environmental sustainability practices being examined in this study, which are solid waste management, water resources management, green office practices and education and awareness. The indicator will be a guideline to determine the level of environmental sustainability for a university campus that help in improving the sustainability of the dormitories. By using the indicator, all dormitories in UKM will be rated according to their performances and this will urge them to compete among themselves to achieve the highest ranking, thus at the same time, a more sustainable environment for a dormitory will be created.

The main objective of this study is to find an appropriate method that can be used to measure the level of sustainability for a campus dormitory. All dormitories will be evaluated equally based on their practices and the scores will be given according to their performances.

\subsection{The Importance of an Indicator for Campus Sustainability}

The purpose of establishing environmental sustainability indicators is to obtain the information on the current sustainable practices and thus to identify what sort of improvement initiatives required to be provided. Improving the basis for sound decision making, integrating many complex issues while providing simple signals 
that a busy decision maker can understand, is a high priority. At a time when modern information technologies increase the flow of information for rapid assimilation while making it possible to explore issues further as needed and this is the goal for indicators (Bedrich \& Arthur, 2007).

By taking the campus dormitory as the scope of study, the decision maker that is stated here are the dormitory administration committee members. By giving them a clear option to determine complex issues, a lot of problems can be solved easily at a faster rate. Sometimes, complex explanation of the indicator may confuse the decision makers, thus making them ignoring the issues altogether. When evaluated at regular intervals, an indicator can point out the direction of change across different units and through time (Remigijus et al., 2009). Thus, green indicators are information concern on sustainability, which may change over time.

\section{Method}

Figure 1 shows the overall methods used in this study. Started with preliminary study in the area of sustainability and its relations with dormitories. Research scopes, goals and objectives were finalized at this stage.

Preliminary Study

-Identify the areas of study
Establishment of Green Dormitories Indicators

- Establishing appropriate guidelines that can be applied across the dormitories in UKM

-Seek the views and consent from dormitory representative to the use of Green Dormitory Indicators

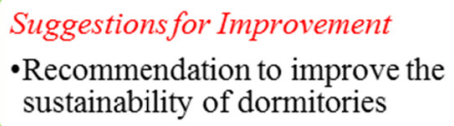

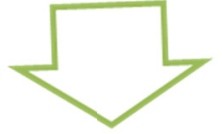

Appraisal and Rating of Dormitories

-Measure the sustainability level of dormitories and compare their achievements

Figure 1. Flow chart for green dormitories indicators study

\subsection{Establishment of Sustainable Campus Indicator for Dormitories}

There are various aspects pointed out by researchers to be considered when preparing Green Campus Indicator for this study. The following is the lists of sustainability practices being reviewed:

1. Frangipani Resort and Spa, Langkawi - Malaysia's Green Hotel

2. Guideline of UI Green metric - University of Indonesia

3. ASEAN Green Hotel Standards

4. University of Maryland Sustainability Progress Report

5. Handbook on the establishment and implementation of Bandar Lestari

6. Handbook on the establishment and implementation of Sekolah Lestari

7. Green Key Eco-Rating Program.

Green practices by Frangipani Resort and Spa, Langkawi were taken into consideration and input in this study. Mr. Anthony Wong Kim Hooi as owner's, his effort and interests in implementing green concepts succeeded to establish the resort standing in the eyes of the world from numerous of their achievement nationally and internationally. As they were established as one of the Malaysia's Green Hotel by ASEAN since 2010, a lot of their practices, improved by times and also seem practical to be implemented in dormitories. From the simplest practices such as reuse old woods for their signage to the making of the detention pond, which later channeled to their garden, all are under its owner's supervision.

Apart from that, a guideline of UI Greenmetric sustainable campus indicator prepared by the University of Indonesia committee members. The UI Greenmetric World University Ranking established in 2010. The aim of this ranking is to provide the result of online survey regarding the current condition and policies related to the greening of campuses and improving sustainability in universities all over the world (Universitas Indonesia, 
2012). There are six categories included setting and infrastructure, energy and climate change, waste, water, transportation, and education there are 33 indicators were used to calculate the ranking score in their third version (2012). UI Greenmetric was accepted worldwide and they able to attract 215 institutions in their third year of ranking published.

Next is the ASEAN Green Hotel Standards. There are 11 criteria listed for measuring the green practices, which are as follows:

- Environmental policies and actions for hotel operation,

- Use green products,

- Collaboration with the community and local organizations,

- Development of human resources,

- Solid waste management,

- Efficient energy management,

- Efficient use of water,

- Air quality management (indoor and outdoor),

- Control of noise pollution,

- Wastewater treatment and management,

- Management and disposal of toxic chemicals.

By considering hotels and dormitories from the same perspective, which is the main responsibility is to keep the residents comfortable and enjoying their stay at the accommodation, some of those criteria for green hotels listed by ASEAN can also be implemented for dormitories. Thus, it is also possible to bring Green Hotel Standards into Green Dormitories Indicators since there are both on the same perspective. Various other green indicators were being examined such as the University of Maryland Sustainability Progress Report, Handbook on the establishment and implementation of Bandar Lestari, Handbook on the establishment and implementation of Sekolah Lestari and Green Key Eco-Rating Program were also made into reference during the listing of indicators process.

A detailed study of the elements required as the basis for developing the indicators was done to establish the Green Dormitories Indicators. In this step, numerous aspects related to sustainability activities are taken into considerations. However, only the practices that have the potential to be carried out in the dormitories were taken into consideration. Several experienced personnel at the campus dormitories were interviewed to comment on the proposed green indicators for improvement.

\subsection{Determining the Rating of Campus Dormitories Sustainability}

Each dormitory was evaluated with the Green Dormitories Indicators. Dormitory representatives were selected randomly among the administration fellows. A short interview with the representatives was done during the evaluation. They also gave some suggestions on how to improve the indicators evaluation results. Some problems were identified that are likely to be the reasons of low sustainability practices in the dormitories which directly reflects the individual dormitories sustainability level.

Figure 2 shows the locations of the dormitories on UKM Campus which consists of the following dormitories:

$\begin{array}{lll}\text { 1. } & \text { Kolej Tun Hussein Onn } & - \text { KTHO } \\ \text { 2. } & \text { Kolej Dato' Onn } & - \text { KDO } \\ \text { 3. } & \text { Kolej Rahim Kajai } & - \text { KRK } \\ \text { 4. } & \text { Kolej Antarabangsa Ibu Zain } & \text { - KIZ } \\ \text { 5. } & \text { Kolej Aminuddin Baki } & - \text { KAB } \\ \text { 6. } & \text { Kolej Keris Mas } & - \text { KKM } \\ \text { 7. } & \text { Kolej Ungku Omar } & - \text { KUO } \\ \text { 8. } & \text { Kolej Burhanuddin Helmi } & - \text { KBH } \\ \text { 9. } & \text { Kolej Ibrahim Yaakub } & - \text { KIY } \\ \text { 10. } & \text { Kolej Pendeta Zaa'ba } & - \text { KPZ }\end{array}$




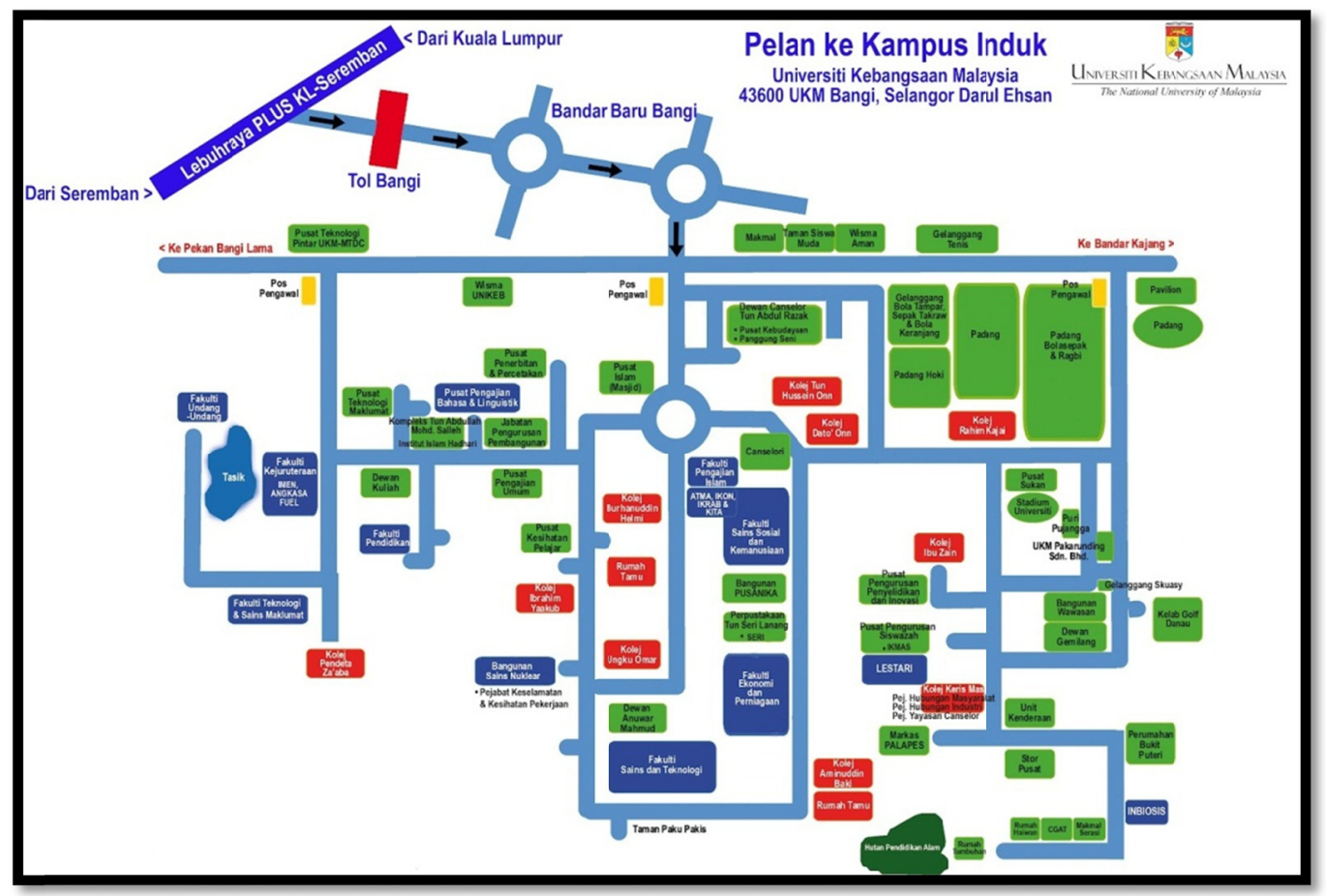

Figure 2. Location of the dormitories in the UKM Campus

When the all the dormitories in UKM were evaluated, the score for each indicator were summed up according to the indicator's section. The total scores for each dormitory will represent its level of sustainability. Besides that, total scores for each indicator were used to identify the sustainable practices that are the most and the least being implemented at the dormitories. From this result, analysis will be done to find the possible reasons for obtaining each score. Further, some suggestions were made on how they should each dormitory provides possible actions need to be taken to improve their ratings.

Finally, all the dormitories will be ranked according to their performances from the scores which were obtained from the Green Dormitories Indicators. Future planning were also suggested to improve the practicality of these indicators which indirectly will help to improve the environmental sustainability level of all dormitories in UKM.

\section{Results \& Discussion}

\subsection{Green Campus Dormitories Indicator}

Resulted from previous established indicators reviewed, a list of green dormitories indicators was made up. Those indicators are shown in Table 1.

Table 1. Proposed green dormitories indicators

\begin{tabular}{ll}
\hline ISPECTS & INDICATORS \\
\hline & - Recycle bins facility \\
& - The use of reusable items \\
& - Reduce the use of plastic \\
1: Solid Waste Management & - Minimize the use of polystyrene in the cafeteria \\
& - Kitchen waste separation \\
& - Monitoring the amount of solid waste generated \\
\hline \multirow{2}{*}{ 2:Water Resources Management } & - Monitoring of recycling practices \\
& - Having an adequate water supply \\
\hline
\end{tabular}




\begin{tabular}{|c|c|}
\hline ASPECTS & INDICATORS \\
\hline & $\begin{array}{ll}\text { - } & \text { Rain Water Harvesting System } \\
\text { - Innovation to reduce usage of water } \\
\text { - Water conservation program }\end{array}$ \\
\hline 3: Green Office Practices & $\begin{array}{ll}\text { - } & \text { Waste reduction practices } \\
\text { - } & \text { Recycling practices } \\
\text { - } & \text { Saving energy and water } \\
\text { - } & \text { 'Green practices' in decorating the office } \\
\text { - } & \text { Appoint staff as 'Green Leader' }\end{array}$ \\
\hline 4: Education and Awareness & $\begin{array}{l}\text { - Have a special committee of college sustainability } \\
\text { - Conduct awareness programs at the college level } \\
\text { - } \quad \text { Following any environmental program at the university } \\
\text { - The environmental program conducted at the national level } \\
\text { - The environmental program conducted at the international level }\end{array}$ \\
\hline
\end{tabular}

\subsection{The Ratings of Campus Dormitories Sustainability}

Figure 3 shows the total results extracted from the indicators. It demonstrated that green office practices have the highest score as compared to the other three categories which are solid waste management, water resources management and education and awareness. There are some low scores that may result from lack of environmental sustainability activities organized in UKM which lead to low awareness among the office staff members. Solid waste management category is ranked as the second highest score among them as compared to green office practices. Every dormitory had contributed their scores in this category. This result may contribute from numerous activities done in UKM related to waste management practices in the recent years.

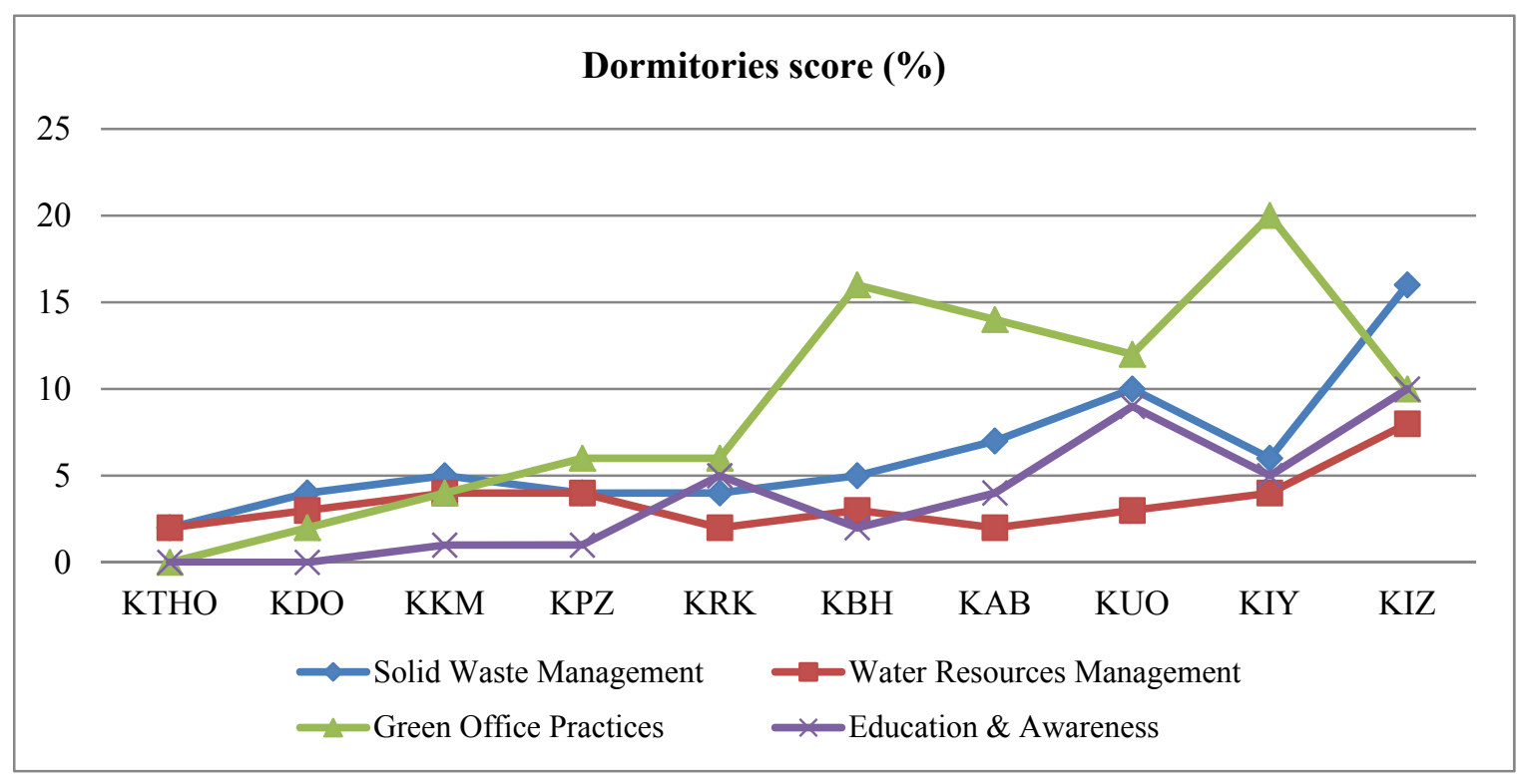

Figure 3. Dormitories score (\%) by in different categories

Figure 4 shows the ranking for all dormitories. These results reflect their sustainability level as measured using Green Dormitories Indicators. Ibu Zain International Student Hostel (KIZ) had obtained the highest score, which is $44 \%$, while Tun Hussein Onn College is the lowest with only $4 \%$. It seems that the administration practices of an individual dormitory will determine the category that they will be performing the best. This is because KIZ admin aim and focused are in the sustainability aspects while KTHO admin focus area in Reserve Officer Training Unit (ROTU). The rest of others dormitories are at an average score of $10-30 \%$. 


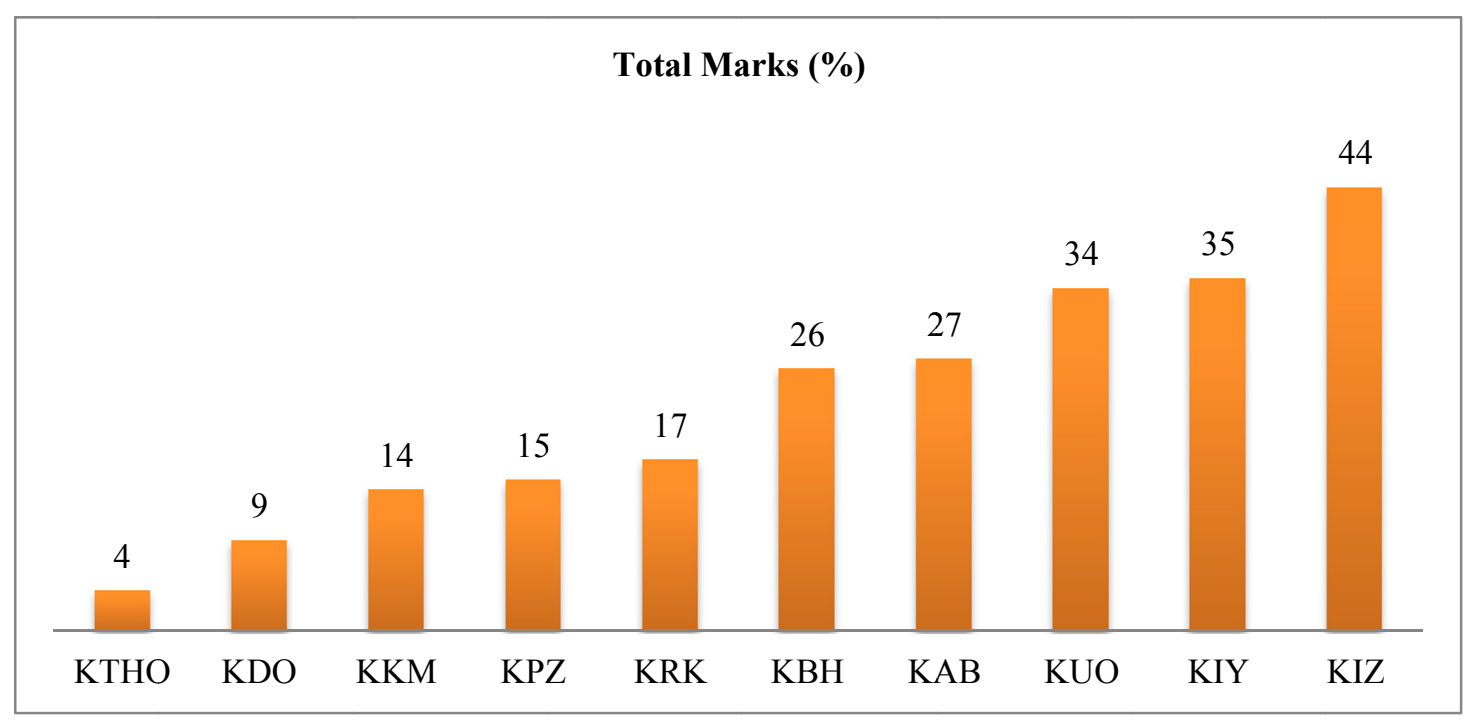

Figure 4. Dormitories ranking

Apart from that, education and awareness programs done by the dormitory administration had directly increased the sustainability practices, and thus they scored higher ranking. This aspect is important for the knowledge and information regarding sustainability will be spread out throughout the dormitory residents, thus making it easier to develop a proper planning for an awareness program to be conducted. From the results obtained indicated that all dormitories had scored very low with the highest of $44 \%$ and lowest is $4 \%$ with an average of $10-30 \%$. It can be concluded that the overall Green Dormitory Indicators achievement for all dormitories on the campus is very low, thus indicating that environmental sustainable practices is not being implemented well at the campus. A lot of aspects need to be improved in order to ensure the campus environments are more environmental friendly.

\section{Conclusions}

The main objective of this study is to find an appropriate method that can be used to measure the level of sustainability for a campus dormitory. All dormitories were evaluated equally based on their practices and the scores will be given according to their performances. The Green Dormitories Indicators which were developed from this study has four environment sustainability categories. Besides that, there are a few suggestions provided in the indicators that will help the dormitory administration to find methods in increasing their dormitories sustainability levels.

Green Dormitories Indicators and its ranking provide opportunities for each dormitory to conduct some actions in order to accumulate better results and therefore achieve a better ranking if evaluation is done annually. Green Indicators can be a framework and a standard guideline for constructing a green dormitory and the whole campus, and thus help universities to green their overall activities.

Thus, it is recommended that all dormitories on UKM campus to use the Green Dormitories Indicators in order to measure the level of environmental sustainability from time to time. By doing so, all dormitories will be inspired to enhance environmentally sustainable practices, thus may provide a better surrounding.

\section{Acknowledgments}

This research was funded by UKM with research grants (DPP-2013-063 and DPP-2013-064). This support is gratefully acknowledged.

\section{References}

Bell, S., \& Morse, S. (2008). Sustainability Indicators, Measuring The Immeasurable?. Earthscan, UK.

Chiang, C. C. (2010). Recommended Sustainable Practices in Malaysia. Universiti Teknologi Malaysia.

Ciegis, R., Ramanauskiene, J., \& Startiene, G. (2009). Theoretical reasoning of the use of indicators and indices for sustainable development assessment. Inzinerine Ekonomika-Engineering Economics, 3(63), 33-40.

Hasbi, Z. (2008). Kehidupan Lestari Di Kawasan Pejiranan Perumahan Industri: Kajian Kes Di Pasir Gudang. Universiti Teknologi Malaysia.

Jabatan Alam Sekitar Malaysia. (2010). Era Hijau Ke Arah Generasi Lestari. Keluaran Ketiga. 
Johnson, J. A. (2006). Designing New Housing at the University of Miami: A Six Sigma. Quality Engineering, $18,299-323$.

Karim, O. A. (2006). Kajian Kualiti Air Tasik Kejuruteraan UKM ke arah mewujudkan Kampus Lestari dan Mesra Alam. Jurnal Kejuruteraan, 18, 57-64.

Kementerian Perumahan Dan Kerajaan Tempatan Malaysia. (2006). The Study of National Waste Minimization.

Moldan, B., \& Dahl, A. L. (2007). Sustainability Indicators: A Scientific Assessment. London: Island Press.

Norfadillah, D., Hashim, H. S., \& Ali, N. (2011). Tahap kelestarian pelajar Universiti Kebangsaan Malaysia ke arah kampus lestari. Jurnal Personalia Pelajar, 14, 1-10.

Verma, S. C. (2010). The eco-friendly Tharu tribe: a study in socio-cultural dynamics. Journal of Asia Pacific Studies, 1(2), 177-187.

Wattanasaroch, K. (2012). Development of Green Dormitory Standard for Mahasarakham University. The Social Sciences, 7(2), 216-223.

Zain, S. M., Basri, N. E. A., Basri, H., Zakaria, N., Elfithri, R., Ahmad, M., Ghee, T. K., \& Khan, S. Y. dan I. A. I. (2011). Keprihatinan Amalan Kitar Semula Membentuk Sikap dan Tingkah Laku Lestari. Kongres Pengajaran dan Pembelajaran Universiti Kebangsaan Malaysia.

\section{Copyrights}

Copyright for this article is retained by the author(s), with first publication rights granted to the journal.

This is an open-access article distributed under the terms and conditions of the Creative Commons Attribution license (http://creativecommons.org/licenses/by/3.0/). 